\title{
Future of Railways - in Open Systems?
}

\author{
Dmitry A. Macheret ${ }^{\dagger}$
}

\begin{abstract}
The article suggests criteria of dividing transport systems into systems of limited and open access. Possibilities of implementing principles of the open access in conjunction with the adaptive control at the railway transport have been analyzed. The author makes a grounded conclusion that the development of transport systems based on the open access and adaptive control can play a positive role in overcoming the global instability of the economy and form prerequisites of its stable grows.
\end{abstract}

Keywords : Railway transport system, Open access, Adaptive control, Infrastructure, Innovation reforms, Crisis, Self-moving car

\section{Introduction}

Despite the fact that severity of the crisis effects have subdued and there are visible tendencies to the GDP growth in the leading world economies, these tendencies have unstable nature and the world markets (foreign exchange, stock exchange, and oil markets) undergo fever fluctuations now and then. According to the estimation of many economists the crisis, that was thought to be over, was only the first wave of the crisis phenomena.

The second wave is possible, but on the one hand side it will not be very strong and on the other - after it passes there will be a one more wave, then another one and so on. The crisis will last for five years".

The main reason why there is no fast normalization process in the world economy and no fast recovery of its stable dynamic growth the scientist sees in the fact that "the world economy does not have a real motor. The period of innovation pause has set in, there are no big inventions yet that would give birth to additional flows of innovations.

It is a brake after the long boom during which personal computers, Internet and mobile communication were introduced. We do not see anything similar now."

The conclusion from this argument is that the final outcome of the world economy from the "waves" of the cri-

\footnotetext{
Corresponding author: United Scientific Council at RZD

E-mail : macheret@vniizht.ru
}

sis is not the question of time itself ( 5 years or another period) but the question of new large-scale innovations that would serve as a "motor" of the strong growth. Time here is necessary but not a sufficient condition. New innovative ideas targeted not even at todays demands but at tomorrow's and their effective implementation are needed.

Reasons for these cyclic fluctuations and crisis phenomena in the economy were analyzed in detail in research work [4]. The crisis overcome "formula" was also determined there: "innovation investments based on real savings that allow to increase productivity and real efficiency of production".

\section{Main Part}

With this regard the question arises - what role in the crisis overcome and transition to the stable economic growth phase can innovations in transport play including the railway transport? The previous phase as it has been noted was based basically on innovations in the sphere of communication technologies that have gone through revolutionary changes in the last decades. Meanwhile there were no equal by scale and depth changes in transport.

The stem of the market economy is barter transactions and goods exchange processes with its material base - the system of communications. Revolution in the means of communication, of course, facilitated development of goods traffic flows and general increase in economy efficiency, but it also promoted "virtualization" of the econ- 
omy that became one of the reasons of the global crisis. The turn to the growth of real efficiency based on production [5] demands innovations in the system of delivering of real values - goods, i. e. in the transport system.

Revolution in the means of transport communications and primarily in the railway traffic [6] and the marine transport in the XIX century played a significant role in the onset of the epoch of contemporary economic growth.

A detailed analysis of the railway transport development allowed to make a conclusion that the railway transport enters the third phase of its evolution - the phase of the innovative renaissance, which is characterized by the renewal of the railway network expansion on the new technological basis along with the growth of macro economical role of the railways [7].

Logic of the global economy and global transport systems demands a certain balance in the development of all transport modes. It means that the phase of innovative development of one of them must be supported by the adequate changes at other transport modes. It is possible to apply the main criteria of innovation transformations defined for the railway transport - cutting costs and increasing the delivery speed for freight and passenger traffic - to all modes of transport [7].

And it is reasonable to consider a one more aspect quite important from the economic view point - procedure of getting access to the transport systems.

The necessity to provide nondiscriminatory access to the infrastructure has already become "a general point" in the programs of transport reformation and development, primarily in the railway transport. As P. Pittman notes, "the reformers display an obvious favour to the policy of "nondiscriminatory access". No matter whether the company that owns the infrastructure and operates it has the right to possess and operate trains, most of the reformation plans demand such a restructuring of the railway sector that would allow all railway transport companies to have equal terms of access to the infrastructure" [8. p. 142].

The problem of the nondiscriminatory access to the infrastructure arises not by chance in the railway transport. As it is stated in the article by professor B. M. Lapidus the Chairman of the International Railway Research Board at International Union of Railways [9], that at the railway transport due to its technical and technological peculiarities the infrastructure plays the leading role and the principle of precise execution of instructions from the train traffic control unit and the train traffic schedule works. Opposite to this at highways "everything that is not forbidden is allowed" and every participant can undertake any actions to achieve his goals in the framework of general limitations transmitted through traffic lights, road signs and road layout. Users of marina transport feel even freer as the infrastructure practically does not limit abilities of ships to move according to the chosen direction and speed.

It seems to be reasonable, using terminology offered by D. North, J. Wallis, B. Weingast for social systems [10], to distinguish transport systems of limited and open access. The main criteria of such differentiation is the level of impersonality (or opposite to this, personification) of users` rights to access. From this view point marina and automobile transport can generally be considered to be open access systems while the railway transport - a limited one.

It is a historical criterion whether the system has open or limited access to its transport infrastructure.

It is interesting that the first railway systems in England and in the USA were built on the basis of a "main line" model or a "channel"; and it was guaranteed - sometimes even through legislative acts - that the railway is open for any user who paid the fee for using it and who observed the rules of the railway usage. This model of vertical integration along with the competition had obviously functioned rather successfully until the cargo transportation had been carried out by horses. However, after locomotives were put into practice it turned out that the usage of transport vehicles with both horse and locomotive traction power at railways was inefficient and very complicated. As the owners of railways used to be the only owners of locomotives, the model of a 'main line' was rather quickly rejected and the railway turned into an integrated monopolistic enterprise that owns the track and managers trains [11. p. 13].

In contemporary conditions of the railway transport reformation in West Europe efforts are undertaken to separate transportation from the infrastructure in order to provide an open access of users to the railway infrastructure. Never the less the every day coordination of many railway companies on one and the only railway track turned out to be not an easy task [11, p. 17], due to the above-mentioned technological peculiarities. Even in conditions when integration of the transporter and the infrastructure owner is preserved and only the wagon fleet is separated, as at the Russian Railways, considerable difficulties arise in organization of the transportation process.

However it is possible to point out a dialectical change (according to the low of negation) in the level of freedom of access to the railway infrastructure: primarily free at the dawn of the sector's existence with the horse traction power usage; then - no free access, and, finally, there is a tendency to return to the maximum access nowadays.

What refers to the non rail land communication lines the level of freedom of access to them also has been 
undergoing some changes. One can recall control by medieval landowners over transit through their lands, free travel in the framework of established centralized states in New Times period and current control over traffic at motor highways, where the principle of impersonification (i. e. equal rights regardless person) of traffic participants is observed far not always and everywhere.

The main conclusion to be made out of this discourse is that the level of openness of transport systems is 1) different and 2) historical.

Though strengthening access limitation is often imposed by objective (including technological) factors, economic theory has proved the advantages of open access systems that have a much higher adaptive effectiveness, i. e. capabilities to adjust to dynamic changes [10].

It should be highlighted that according to the research studies of the Seoul University based on the mathematical modeling [12] to minimize 'traffic jams' on roads it is necessary to switch from the centralized control over the road traffic to the adaptive control of each car based on the on-board computers that monitor movements of other cars and change the speed mode according to it by a certain algorithm. The Seoul scientists see the future of the automobile traffic in complete switch to the "free" type of the transport flow.

There is a certain interest in working out opportunities of using the principle of a "free" traffic flow with adaptive control at the railway transport as well.

It looks as if these principles totally contradict already set up approaches to the organization of railways transportation. But exactly these principles can turn railways into a transport system with open access and be the basis for truly innovative changes at the railway sector.

Elaboration of certain technical and technological proposals in this direction goes beyond the limits of this work. Never the less, it is important to note that a number of innovative research studies, economical aspects of which were scrutinized in work [13], are conducted in the framework of this approach.

Here we speak about a self-moving freight car CargoMover designed by Siemens TS and intended for operation in conditions of a common railway network. It is designed to move in an autonomous mode from one branch to another along the lines of general usage, that stipulate time gaps in the train traffic schedule. CargoMover can be integrated for transportation within a plant rails, can efficiently manoeuvre, it can be used for transportation of containers to terminals. Thus, CargoMover is a unique multifunctional railway transport for fast cargo transportation for short distances.

High economic efficiency of transportation is provided due to the automatic operation of the car.

Principles of "open access" can be practiced on the basis of such cars and adaptive traffic control at the railway transport with further their dissemination to formation and organization of full train traffic.

The following organization of railway systems based on the principles of open access and adaptive control is possible: self-moving cars equipped with computer adaptive control systems will move freely along the lines with low level of loading (the so called branch lines) and for the long and ultra-long distances along the main lines movement they will be formed into full trains at automatic interchange yards.

At the same time engagement of each car into this or that train will be fulfilled of the basis of combination of the adaptive car traffic control that 'guides' it along its individual route and automatic system of the interchange yard control that provides effective train formation on the assumption of the maximum infrastructure loading and support of strict traffic schedule.

In this way combination of the free access to the railway system with its traditional advantages - the regularity of traffic, high carrying capacity and low transportation cost - will be achieved. At the same time due to automation the labor efficiency will be increased significantly, which is very important in conditions of serious demographic problems in the most developed countries. (It is obvious that such problems will evoke in quickly developing China as well in several decades).

\section{Conclusion}

Practical implementation of the suggested methods at the railway transport regardless their apparent futuristic character will be not a more and not less revolutionary change as the emergence and dissemination of the mobile communication.

It is obvious that the new principles and technologies first should be located at new lines and proving grounds, meanwhile it is necessary to provide their interconnection with traditional technologies functioning at the main railway network.

Provision of open access to the railway transport is also necessary for including it into open intermodal system of global goods traffic, the idea and the principal scheme of which were suggested in work [14].

Drastic innovative transformation of transport systems on the principle of open access and adaptive control can become the "motor" which is so needed by the world economy to come out from the "waves" of the crisis to the firm ground of stable growth. 


\section{References}

1. Ladislav, F. (1985). "Thermal interaction of long welded rails with railway bridges," Rail International, Vol. 16, No. 3, March, pp. 5-24.

2. Magued, M. H. (1988). "Rail-structure interactions for short span railway and transit bridges," Canadian Journal of Civil Engineering, Vol. 15, pp.157-166.

3. Евгений Ясин. Новая реальность., (2011). http://ej.ru/ 19 сентября

4. Мачерет Д.А. Экономический кризис и транспорт, (2010). Мир транспорта, № 2.

5. Мачерет Д.А. Производительность фундаментальная основа экономической эффективности, (2010). Экономика железных дорог., № 7.

6. Мачерет Д.А. Создание железных дорог и экономический рост ,(2011). Мир транспорта., № 1.

7. Лапидус Б.М., Мачерет Д.А. Эволюция жеезнодорожного транспорта: на пути к инновационному ренессансу, (2,Lest) Вестник ВНИИЖТ. , № 1.
8. Питтмэн Р. (2008). Реформа российских железных дорог и проблема недискриминированного доступа к инфраструктуре // Экономическая школа. Альманах, том 6. Конкуренция и конкурентная политика. , М.: Вершина,

9. Лапидус Б.М., (2011). Пространственные условия конкуренции // Экономика железных дорог. № 10.

10. North D.C., Wallis J.J., Weingast B.R. (2009). Violence and Social Orders: A Conceptual Framework for Interpreting Recorded Human History. N.Y.: Cambridge University Press.

11. Питтмэн Р. Вертикальная реструктуризация инфраструктурных отраслей в странах с переходной экономикой, Экономическая школа. Аналитическое приложение., № 1.

12. Математики рассчитали как вести себя в пробках.// http://news.rambler.ru/11141645/ 19 сентября 2011 г.

13. Мачерет Д.А., Рышков А.В. (2007), Инновации и ресурсы: поиск баланса, Мир транспорта., № 1.

14. Мачерет Д.А. От логистики к системе глобального товародвижения , (2006) Мир транспорта., № 3.

Received(July 5, 2012), Accepted(July 30, 2012) 